\title{
Kiven lumo
}

\section{Kokemuksia geologian opetuksesta kansalais- ja työväenopistoissa}

\author{
JUKKA HILDÉN
}

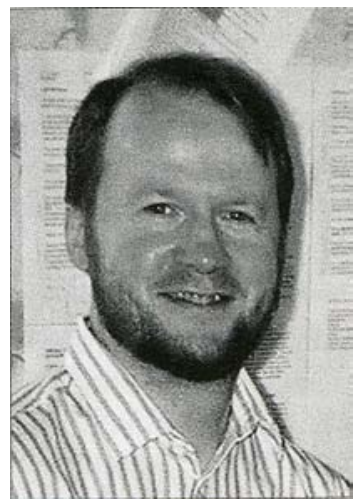

Kansalais- ja työväenopistot - määrältään noin 250 opistoa - täyttyivät jälleen tänä syksynä innokkaista aikuisopiskelijoista. Vuosittain kansalais- ja työväenopistoissa opiskelee liki 800000 suomalaista. Kysytyimpiä ovat vieraat kielet, kättentaidot ja liikunta. Tässä kuvattu geologinen kivikurssi on vapaan sivistystyön piirissä erikoiskurssi. Sen hyväksyminen opetusohjelmaan riippuu paljon rehtorin tai yhteiskunnallisten aineiden päätoimisen opettajan henkilökohtaisesta kiinnostuksesta kiveen ja alan ymmärtämisestä.

Geologisen kivikurssin (erotuksena kivenhiontakurssista) alkaminen edellyttää usein neljää seikkaa: 1) opisto hyväksyy kurssin ohjelmistoonsa, 2) minimiopiskelijamäärä täyttyy, 3) kurssia mainostetaan kivikerholaisille ja kivenhiontakurssilaisille sekä 4) kurssimaksu pidetään kohtuullisena.

Opiston kurssiesitteessäja muussa mainonnassa tulisi selvästi mainita, minkä luontoinen kivikurssi on: 1) kivenhiontakurssi (gemmologiakurssi) vai 2) geologinen kivikurssi. Näillä kahdella ei ole juuri mitään tekemistä toistensa kanssa paitsi, että ne täydentävät hyvin toisiansa.

Kivenhiontakursseja on käsittääkseni järjestetty useimmissa työväen ja kansalaisopistossa gemmologien ja kiviharrastajien toimesta. Geologiset kivikurssit ovat huomattavasti harvinaisempia. GTK on 2000-luvulla antanut geologiakoulutusta Kainuun pakallisväestölle, opettajile ja koululaisille. Itse osallistuin 2000-luvun alussa kouluttajana Suomen koulujen luonnontieteiden opettajille tähdättyyn geologian ja geomorfologian täydennyskoulutukseen (LUMAprojekti), jonka järjesti Helsingin yliopiston tutkimus- ja koulutuskeskus Palmenia.

\section{Mitä on yleissivistys?}

Vapaan sivistystyön opistoissa on paljon eri alojen päätoimisia opettajia. Luontoalan päätoimista opettajaa (geologiasta puhumattakaan) ei ehkä löydy yhdestäkään opistosta. Näin on, vaikka tieteet ja opiskelualat jaetaan inmis- ja luonnontieteisiin. Vapaan sivistystyön opistot ovat varsin inmistiedepainotteisia.

Kansalaisopistojen inmistiedepainotteisuus johtuu tietysti ihmisistä, jotka hakeutuvat vapaan sivistystyön pariin: he tarjoavat oman alansa kursseja. Luonnontieteiden edustajat tarjoavat kursseja huomattavasti vähemmän johtuen ehkä suuremmasta sitoutuneisuudesta ja aikapulasta, ehkä myös siitä, että he tietävät kurssille tulevien ihmisten olevan selvillä siitä, ettei luonnontieteiden kursseista ole heille samaa välitöntä hyötyä kuin esimerkiksi kieli- tai tietokonekursseista. Lisäksi luonnontieteitä pidetään vaikeina. Sitäkin enemmän - nimenomaan luonnontieteiden suhteen - pitäisi korostua työväen- ja kansalaisopistojen alkuperäinen tarkoitus: ei tuloksen tekeminen, vaan yleissivistyksen tarjoaminen kaikille. Geologia on yleissivistävä aine. 
Yhteiskunta on tänään niin hyötyajattelun lumoissa, sen läpikotaisesti uuttamaa ja uuvuttamaa, että yleissivistyksen alkuperäinen merkitys on hämärtymässä. Ylioppiolaskokeissa saa vapaasti valita aineet, jotka kirjoittaa - vaikka kuusi kieltä (joilla tähän mennessä on sujuvasti vaiettu, vaikka nyt ajat ovat muuttuneet). Kohta sama tilanne voi olla lukio-opetuksessa, peruskouluissa... Ollaanko unohtamassa, mitä yleissivistys on?

Itse kuitenkin hämmästyn jatkuvasti sitä, miten suomalaiset ovat kivistä kiinnostuneita; eivät vain kivikurssille tulevat, jotka edustavat kiinnostuksen jäävuorenhuippua. Tuntuu, että melkein jokaisella suomalaisella perheellä on kirjahyllyn alatasolla peltilaatikko täynnä ulkomaanmatkalta, kotimaasta tai mökinrannalta tuotuja kiviä. Tämä osoittaa kiinnostusta kivikuntaan samoin kuin geologiset kysymykset, joita inmiset usein tekevät.

\section{Opistot, missä olette?}

Toinen ehto kurssin alkamiseksi on vähimmäisosallistujamäärä. Kurssille ilmoittautuneita on oltava - opistosta riippuen $-7,8,10$ tai 12 . Vaikka opistolle tulee tukea myös muualta, niin kurssilaisten tuomat maksut ovat budjetissa erittäin tärkeitä. Tappion välttäminen tuntuu nykyään olevan tärkeämpää kuin mikään - edes kurssin toteutuminen. Työväen-, aikuis- ja kansalaisopistot ovat omienkin sanojensa mukaan businesslaitoksia, varsinkin tietyt pääkaupunkiseudun opistot.

Kerran Suomen isoimpiin kuuluva aikuisoppilaitos kieltäytyi ottamasta kurssiani ohjelmistoonsa, koska edellisellä kerralla osallistujia oli vain minimimäärä eli 10 (mikä todellisuudessa on ihannemäärä). Tuli huoli, että jos jälleen ilmoittautuu "vain" 10, niin tilanne uhkaa mennä plus-miinusnollapeliksi. Opisto ei silloin nettoa - mutta eivät kiinnostuneetkaan saa oppia. Missä olet, oi työväenopisto?

Isoilla opistoilla tuntuu olevan korkeampi osallistujien minimimäärä kuin pienillä, joissa paremmin näyttää vallitsevan vanhan ajan valistusmeininki. Puhun Pääkaupunkiseudusta ja sen kehyskunnista. Näissäkin opistoissa tilanne on kuitenkin muuttumassa. Erään kehyskunnan opisto olisi alkanut kivikurssin neljällä opiskelijalla sillä perusteella, että kyseessä on erikoiskurssi. Näistä neljästä kuitenkin yksi perui, joten kurssi ei voinut näin pienenä alkaa. Sitten opistolla vaihtui päätoiminen opettaja. Helsingistä muuttanut yhteiskuntatieteilijä ei ottanut kuuleviin korviinsa puhetta mistään erikoiskurssista tai siitä, että sellainen voisi alkaa neljällä. Lopulta kurssi alkoi noin 10 osallistujalla. Syynä alkamiseen oli se, että opisto oli mainostanut kurssia aiemmin päättyneen kivenhiontakurssin osallistujille. Jos lähiseudulla on kivikerho, myös sinne tulisi kurssia mainostaa. Kun näin tehdään, kurssi todennäköisemmin toteutuu.

Vähemmässä määrin geologiakurssin toteutumiseen vaikuttaa se, että kurssin hinta pysyy kohtuullisena. Ylihinnoittelu pitää geologisen kivikurssin osallistujaluettelon melkein tyhjänä. Noin 28 tunnin kurssin kohtuullinen hinta on siinä 35-45 euroa. Kerran minulla oli 28 tunnin kurssi, jonka hinta oli vain 20 euroa ja toisessa kunnassa tätä hieman lyhyempi kurssi, joka hinnoiteltiin 71 euroksi. Kahden kympin kurssi toteutui noin 15 osallistujalla, 71 euron kurssi peruuntui, koska ilmoittautuneita oli muistaakseni vain kaksi. Hinnalla oli ehkä merkitystä - vaikkakin edullisemman kurssin kunnassa pidin kivikurssia vasta ensi kertaa, kun taas kalliimmassa kunnassa olin pitänyt jo useita kursseja ja kiinnostus siellä oli jo vuosia ollut laimenemaan päin. Mututuntumana sanoisin, ettei hinta kuitenkaan ole ratkaiseva tekijä niillä, jotka ovat todella kivistä kiinnostuneita. Tällaisia on geologiakurssilaisista valtaosa. He ovat myös erittäin motivoituneita.

Vaikuttaa, että vauraus, korkea koulutustaso ja kivikerhon puuttuminen kunnasta edistävät kivikiinnostusta ruuhka-Suomessa. "Paras kuntani" on aina ollut Espoo, sitten Järvenpää. Myös Porvoossa kurssini toteutui heti ja täällä tuntuu olevan muutenkin kiinnostusta kiviin.

\section{Kun kurssi alkaa}

Ensimmäiset kivikurssini olivat 32 tunnin mittaisia ja kestivät koko lukukauden. Kerran viikossa kokoonnuttiin luokkahuoneeseen kahdeksi 45 minuutin pituiseksi oppitunniksi. Kurssiin kuului muistaakseni kaksi maastokäyntiä jakson loppupuoliskolla. Kivinäytteitä toin mukanani niin paljon, kuin jaksoin kantaa - jopa niin, että ison laukun pohja repeytyi.

Periaatteeni on ollut alusta lähtien, että geologiakurssi ei saa olla vain "laulua ja leikkiä". Teorialuennot ovat olleet keskeisellä sijalla, alussa jopa liiankin kanssa. 
Nopeasti ymmärsin, että opetuskertojen on oltava monipuolisia. Tässä suhteessa sain neuvoa suorittaessani aikuisopettajaopintojeni opetusharjoitteluja. Sittemmin pyysin kurssiesitteessä oppilaita tuomaan omia kivinäytteitä mukanaan tunnistamista varten. Yleensä kaikilla on ollut näytteitä ja niitä on tuotu sopivasti jokaista kokoontumiskertaa varten. Olen huomannut, että omien näytteiden tunnistaminen on kurssilaisille erittäin tärkeä asia. Vuosia peltirasiassa olleet rakkaat kivet saavat nyt nimen ja synnyn. Ne alkavat "elää". Usein laitan näytteet kiertämään luokassa. Tämäkin on oppilaille tärkeää: oma kivi saa yleistä huomiota.

Kiitän aina, jos kivet ovat tavallisia, sillä juuri niitä ollaan oppimassa: maasälpiä, kvartsia, kiilteitä ja tavallisia kivilajeja. Myös minkä tahansa harvinaisempien näytteiden löytäjää kiitän, mikäli kivet on itse löydetty tai itse louhokselta haettu. Tympäisevää on saada eteensä opiskelijan isoisän isän Casablankan torilta 1800-luvulla ostama 100-lokeroinen, karamellilaatikon väreissä kiiltävä näytelaatikko! Torin myllytettyjen kivien kauppiaalle viittaan usein kintaalla metsään sanoen, että sieltä löytyy kauniimpia ja mielenkiintoisempia kiviä. Kun opettaa kurssilaisten omien näytteiden avulla kivioppiminen on tehokkaampaa ja opettaja säästää vaivan kantaa suuria kivimääriä luokkaan.

Olen pyrkinyt antamaan kurssilaisille Geologian tutkimuskeskukselta (GTK) saatavat ilmaiset malminäytelaatikot. Joskus olen antanut opiskelijoiden tutustua malminäytteisiin kehottaen heitä tekemään kokeita kotikonstisilla mineraalintunnistusmenetelmillä, toisinaan olen itse esitellyt tunnistuksen periaatteet.

Viime aikoina näytelaatikoiden saatavuudessa on ollut ongelmia. Ensin tietyt malmityypit uhkasivat loppua, nyt tilanne on se, että GTK: n Kuopion toimistossa, minne laatikoiden tekeminen on keskitetty (samoin kuin geologian popularisointi ja opetus) olisi kyllä näytteitä, mutta kenelläkään ei ole aikaa valmistaa laatikoita. Nykyaikaa! Olenkin saanut viime aikoina laatikon

Vaikka GTK pihtaa henkilöstön palkkaamisessa, on sille annettava tunnustus siitä, että se jakaa kansalaisille ilmaista materiaalia. Kartat, Tietohippu ja Materia -lehdet ovat hyvää geologian esittelyaineistoa. Vanha GTK: $n$ "Malminetsijän opas" oli hyvä, vaikkakin turhan paljon malmipainotteinen. Uusi "Retkeilijän kiviopas" on paikoitellen hyvä, mutta siinä on käsittämättömän paljon virheitä. Opasta ei ilmeisesti ole riittävästi tarkistettu. Kenelläkään ei tietenkään ole ollut aikaa. Nykyaikaa!

Jossain vaiheessa opetukseeni tuli mukaan diaesitys. Olen ottanut satoja ja taas satoja kuvia lähinnä Uudenmaan mineraaleista, kivi- ja maalajeista sekä pinnanmuodoista. Esitys sijoittuu luokkahuoneopetuksessa loppukevennykseksi toisen luennon jälkeen.

\section{Tuntikehys}

Viime vuosina kivikurssini ovat olleet noin kahden viikon mittaisia. Neljän oppitunnin luento on ollut maanantaisin ja keskiviikkoisin. Neljä tuntia eivät ole liikaa kurssilaisille, mikäli tunnit rakennetaan vaihtelevasti. Olemme viime aikoina aloittaneet kello 17.30. Tuntien rakenne on seuraava: 1) luento, 2) kurssilaisten omien kivinäytteiden tunnistaminen, (10 minuutin tauko), 3) luento jatkuu, 4) diaesitys. Lopetamme kello 20.40. Neljänkään oppitunnin jälkeen kurssilaiset eivät vaikuta pitkästyneiltä. Tämä johtunee siitä, että olen pyrkinyt tekemään tunnit vaihteleviksi.

Molempina tai vain jälkimmäisenä lauantaina on ollut 6-7 oppitunnin mittainen maastokäynti. Tämä on kurssin kohokohta. Sulan maan aikaan olemme käyneet tutustumassa kurssipaikkakunnan geologisiin kohteisiin. Koska olen "keikkageologi", en aina tunne lähiseudun kohteita, joten joskus olen kysynyt kurssilaisilta. He ovat opastaneet mielenkiintoiselle kohteelle.

\section{"Maailman kaunein kivi"}

Syksyn 2004 Porvoon kurssia varten oli välttämätöntä mennä ennalta etsimään Virvikin pallokiveä, mikä löytyikin pienen haun ja lähitalosta kyselyn jälkeen. Tämän löytäminen oli muuten suuri geologinen elämys. Mainostaminen oli nyt helpompaa:"Maailman kauneinta kiveä etsimässä!". (Mielestäni pallokivet ovat kauneimpia kiviä ja Virvikin kivi kaunein niistä pallokivistä, joita olen nähnyt). Lumisena aikana olemme vierailleet Helsingin yliopiston geologian museossa ja tehneet kaupunkien keskustoissa kierroksia tutustuen niiden luonnonkivisiin rakennelmiin. Talvella voi tutustua myös pääkaupunkiseudun kallioleikkauksiin (aina joku seinä on vapaa lumesta) ja Heurekan kivitarhaan (aina jotkut sivut ovat lumettomia). 